\title{
Clinical Relevance of Circulating Immune Complexes in Human Leukemia
}

\author{
ASSOCIATION IN ACUTE LEUKEMIA OF THE PRESENCE OF IMMUNE \\ COMPLEXES WITH UNFAVORABLE PROGNOSIS
}

\author{
Nicole A. Carpentier, Ghislaine T. Lange, Denis M. Fiere, Gilbert J. Fournie, \\ Paul-Henri Lambert, and Peter A. Miescher, World Health Organization \\ Immunology Research and Training Center, Blood Transfusion Center and \\ Department of Medicine, University of Geneva, 1211 Geneva 4, Switzerland
}

\begin{abstract}
A B S T RACT The occurrence of circulating immune complexes was investigated in 467 serum samples from 230 leukemia patients using the $\left[{ }^{125} \mathrm{I}\right] \mathrm{Clq}$-binding test. There was an increased serum [ $\left.{ }^{125} \mathrm{I}\right] \mathrm{Clq}$-binding activity in $40 \%$ of patients with acute myeloid leukemia, $23 \%$ with acute lymphatic leukemia, $46 \%$ in blastic crisis of chronic myeloid leukemia, $12 \%$ with chronic lymphatic leukemia, and $13 \%$ with chronic myeloid leukemia. In 48 patients, serum was also tested for soluble immune complexes by the Raji cell radioassay; the correlation between results of the two tests was significant. The Clq-binding material had properties identical with those of immune complexes. It sedimented as 14-28s material on sucrose density gradient. It contained IgG which could be dissociated at acid $\mathrm{pH}$. Its $\mathrm{Clq}$-binding properties could be removed after passage through anti-IgG immunoabsorbant or after a mild reduction-alkylation treatment, but were not sensitive to deoxyribonuclease treatment. Circulating immune complexes were found most commonly during the blastic stage of leukemia.

Remission took place in $75.4 \%$ of patients with no detectable circulating immune complexes at the onset of acute leukemia, but in only $32.7 \%$ of those with detected complexes during this period. Median survival times of the former group of patients were more than 18 mo in acute myeloid leukemia and acute
\end{abstract}

A preliminary report of this work was presented at the 1976 Annual Meeting of the Swiss Society for Internal Medicine, Interlaken, Switzerland.

Dr. D. Fière is from the Department of Hematology, Hopital Edouard Herriot, 69374 Lyon, France. Dr. G. J. Fournie is from the Laboratory of Renal Immunopathology, Centre Hospitalier Régional, 31000 Toulouse, France.

Received for publication 6 December 1976 and in revised form 31 May 1977. lymphatic leukemia and more than $81 \frac{1}{2}$ mo in blastic crisis of chronic myeloid leukemia. The corresponding median survival times in the latter patient group were 64,135 , and 90 days. These findings were unrelated to prognostic features already known.

\section{INTRODUCTION}

Many studies have suggested that human malignant cells possess antigenic determinants which can elicit specific immune responses from the host (1-4). In leukemia, tumor-associated antigens have been mainly detected by the use of xenoantisera to leukemic cells (5-8). Circulating antibodies, leukemic cell-bound immunoglobulins, and lymphocytes which had in vitro cytotoxicity for leukemic cells, have been found in patients with leukemia $(9-13)$.

Whether these immune reactions of the cancer patient play a role in vivo in the disease process is difficult to assess. It is obvious that they are most often insufficient to adequately control the malignant cell proliferation. Interference of humoral factors with the cell-mediated response of the patient to his neoplasm has been proposed as an explanation of the failure of the immume system to control tumor growth, and this is supported by the demonstration in vitro of a specific blocking of lymphocyte-mediated cytotoxicity by the serum of individuals with growing tumors $(10,14,15)$. There is evidence that serum blocking factors may consist of immune complexes (16-19). Furthermore, several studies have indicated that antigen-antibody complexes, possibly related to the tumor, may circulate in blood $(18,20-24)$ or be deposited in tissues (25-28) of patients with different types of malignancy, including leukemia (29). 
The present study was carried out, using the [ $\left.{ }^{125} \mathrm{I}\right]$ Clq-binding test (30) and the Raji cell radioassay (23), to determine the incidence of circulating immune complexes in leukemia and to investigate their relationship to clinical and biological features of the disease and to prognosis. The serum Clq-binding material which was detected was further characterized by immunochemical and physical analysis.

\section{METHODS}

Patients. The patients included in this investigation were hospitalized in Roswell Park Memorial Institute, Buffalo, N. Y.; Hopital Edouard Herriot, Lyon, France; Centre Hospitalier Régional, Toulouse, France; Hopital Universitaire, Liège, Belgium; and the Hopital Cantonal, Geneva, Switzerland. Serum samples were obtained from $100 \mathrm{pa}-$ tients with acute myeloid leukemia (AML), ${ }^{1} 39$ patients with acute lymphatic leukemia (ALL), 28 patients in blastic crisis of chronic myeloid leukemia, 38 patients with chronic myeloid leukemia (CML), and 25 patients with chronic lymphatic leukemia (CLL). When possible, serial serum samples from patients were examined and the level of immune complexes was correlated with the clinical course of the disease. In acute leukemias (AML, ALL, and blastic crisis) 175 of the serum samples were taken from 110 patients at onset of the disease and 20 patients in relapse; the other 103 samples corresponded to the period of complete clinical remission. Sepsis was found in 41 (37\%) of the patients tested at onset of acute leukemia and 6 patients $(30 \%)$ examined in relapse. Increased erythrocyte sedimentation rate was observed in $54.5 \%$ of patients in blastic phase, at the time of serum analysis. Most of the patients were treated by chemotherapy according to the type and the stage of leukemia. In addition, all except 8 of the 38 patients with CML were vaccinated with either bacille Calmette-Guérin (BCG) alone or BCG plus cultured allogeneic lymphoblastoid cells, according to the Sokal immunotherapy program (31).

Collection and storage of sera. Blood was drawn aseptically from patients and allowed to clot at room temperature or at $37^{\circ} \mathrm{C}$ for at least $60 \mathrm{~min}$. It was then centrifuged at $1,500 \mathrm{~g}$ for $15 \mathrm{~min}$ without cooling, and the serum was stored at $-70^{\circ} \mathrm{C}$ until used. Control sera from 68 healthy blood donors were collected in the same way.

Radiolabeled Clq-binding tests. Details of the technique have been previously described $(30,32,33)$. On the day of the test, a portion of radiolabeled Clq was diluted in 3-5 $\mathrm{ml}$ of Veronal-buffered saline containing $1 \%$ normal human serum pool-heated for $30 \mathrm{~min}$ at $56^{\circ} \mathrm{C}$. It was then centrifuged at $18,000 \mathrm{~g}$ for $40 \mathrm{~min}$ to remove aggregated $\mathrm{Clq}$, and the supernate was used for the test. In BioVial propylene tubes (Beckman Instruments Inc., Palo Alto, Calif.), fifty $\mu \mathrm{l}$ of tested serum was mixed with 2 vol of $0.2 \mathrm{M} \mathrm{Na}_{2}$ EDTA (adjusted to $\mathrm{pH} 7.5$ with $\mathrm{NaOH}$ ) and incubated at $37^{\circ} \mathrm{C}$ for $30 \mathrm{~min}$. Then $1 \mathrm{vol}$ of $\left.{ }^{125} \mathrm{I}\right] \mathrm{Clq}$ and 20 vol of $3 \%(\mathrm{wt} / \mathrm{vol}$ ) polyethylene glycol (DAB-7, mol wt 6,000, Siegfried, Zofingen, Switzerland) solution were added to the mixture. The tubes were left in an ice bath for $60 \mathrm{~min}$, then

${ }^{1}$ Abbreviations used in this paper: ALL, acute lymphatic leukemia; AML, acute myeloid leukemia; BCG, bacille Calmette-Guérin; BSA, bovine serum albumin; CLL, chronic lymphatic leukemia; CML, chronic myeloid leukemia; ESR, erythrocyte sedimentation rate; HLA human leukocyte antigen. centrifuged at $1,500 \mathrm{~g}$ at $4^{\circ} \mathrm{C}$ for $20 \mathrm{~min}$. The radioactivity of the precipitates was measured. In each test, heataggregated human gammaglobulins at different concentrations in normal human serum served as positive controls, while normal human serum was used as a negative control.

Results were expressed as percent of $\left[{ }^{125} \mathrm{I}\right] \mathrm{Clq}$ precipitated when compared with the total protein-bound radioactivity obtained by $20 \%(\mathrm{wt} / \mathrm{vol})$ trichloroacetic acid precipitation of $50 \mu \mathrm{l}$ of normal human serum mixed with $50 \mu \mathrm{l}$ of $\left[{ }^{125} \mathrm{I}\right] \mathrm{Clq}$. They were corrected using a modified Farr's formula (34) for the precipitation of radiolabeled $\mathrm{Clq}$ which was observed in normal sera. The normal range of $\left.{ }^{125} \mathrm{I}\right] \mathrm{Cl}$ q precipitation was assessed by the testing of sera from 68 healthy blood donors. The mean value of corrected $\mathrm{Clq}$-binding activity in these sera was $0.0 \pm 2.2 \%$ $( \pm 1 \mathrm{SD})$. The corrected percentage of $\left[{ }^{125} \mathrm{I}\right] \mathrm{Clq}$ precipitated in the serum samples represented the Clq-binding activity of these samples. A serum Clq-binding activity deviating by more than $3 \mathrm{SD}$ values from the normal mean level was considered as positive.

Sucrose gradient fractions and effluents from immunoabsorbant columns were tested in the same way as sera except that for gradient fractions the test was carried out after addition of $50 \mu \mathrm{l}$ of normal human serum to the samples to maintain a suitable concentration of proteins. Sucrose (DBA-7, Merck, Darmstadt, W. Germany) solutions did not influence the results of the test. All the samples were tested in duplicate.

Raji cell radioimmunoassay. The Raji cell assay for detection of immune complexes was performed on 48 sera from leukemic patients and on 22 sera from healthy blood donors, according to the procedure modified and reported by Theofilopoulos et al. (23). The Raji line of lymphoblastlike cells obtained from the Scripps Clinic and Research Foundation (La Jolla, Calif.) was cultured in Eagle's minimal essential medium as described (35). Cells from 72-h cultures were used for the radioimmune assay. Their viability was assessed by trypan blue exclusion before each experiment. The results of this assay were compared to those given by the Clq-binding test applied to the same serum samples. With normal sera, the Raji cell assay gave a mean value of $8.9 \pm 13.0( \pm 1 \mathrm{SD}) \mu \mathrm{g}$ of aggregated human IgG eq/ $\mathrm{ml}$. Values over $48 \mu \mathrm{g}$ of aggregated human IgG eq/ml $(>3$ $\mathrm{SD})$ were considered as positive.

Density gradient studies. Linear $10-40 \%(\mathrm{wt} / \mathrm{vol})$ sucrose gradients in either $0.1 \mathrm{M}$ borate- $\mathrm{NaCl}$ buffer, $\mathrm{pH} 8.3$, or 0.5 $\mathrm{M}$ acetate buffer, $\mathrm{pH} 3.5$, were formed with a two-chamber gradient device simultaneously in three tubes (cellulose nitrate tubes, Beckman, no. 305050). For ultracentrifugation, a SW 65-Ti rotor in a Beckman L2-65B ultracentrifuge was used. Samples layered on gradients varied according to the experiment. In some experiments, 0.5 or $1 \mathrm{ml}$ of tested serum was subjected to ultracentrifugation. In the others, a partial purification and concentration of the Clq-binding material found in the sample was achieved by polyethylene glycol precipitation of serum before the ultracentrifugation: 1 vol of serum was mixed with 4 vol of a $4 \%$ (wt/ vol) polyethylene glycol solution in borate buffer, $\mathrm{pH} 8.3$; the mixture was left on ice for $1 \mathrm{~h}$ and then centrifuged at $2,000 \mathrm{~g}$ for $15 \mathrm{~min}$. The precipitate was gently resuspended in $1 \mathrm{ml}$ of borate buffer, $\mathrm{pH} 8.3$, and centrifuged on a $4-\mathrm{ml}$ sucrose borate buffer gradient at $87,000 \mathrm{~g}$ for $16 \mathrm{~h}$ at $10^{\circ} \mathrm{C}$. Serial gradient fractions of 500 or $250 \mu \mathrm{l}$ were collected, and optical density (OD) patterns were obtained with a 0.3 mm flow cell (Uvicord, LKB-Produkter, Bromma, Sweden) and a logarithmic recorder ( $W+W$ Electronic $A G$, Basel, Switzerland). Clq-binding activity of each gradient fraction was then assessed as described above. 
To test the dissociation at acid pH of the Clq-binding material, gradient fractions from a first ultracentrifuge run, which contained the Clq-binding material, were pooled. Equal volumes of this pool were mixed with 2 vol of

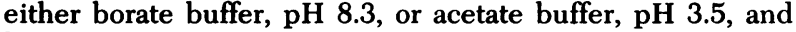
left on ice for $2 \mathrm{~h}$. $1 \mathrm{ml}$ of each mixture was layered on a 4-ml sucrose density gradient of corresponding $\mathrm{pH}$ and centrifuged simultaneously at $271,000 \mathrm{~g}$ for $4 \mathrm{~h}$ at $10^{\circ} \mathrm{C}$. Acid gradient fractions were neutralized immediately after their collection by addition of $0.5 \mathrm{M}$ Tris- $\mathrm{NaOH}, \mathrm{pH} \mathrm{13}$, and left at room temperature for $60 \mathrm{~min}$ before being tested for their Clq-binding activity. In each experiment, a sample of diluted normal human serum was centrifuged in parallel in a control gradient tube. The $19 s$ and $7 s$ peaks of normal human serum OD pattern were used as gradient markers, and the apparent $s$ values were calculated according to Martin and Ames (36).

Immunochemical procedures. Immunoelectrophoresis on gradient fractions from ultracentrifugation was carried out according to the method of Scheidegger (37), using commercial rabbit anti-human IgG ( $\gamma$-chain) and rabbit antihuman IgM ( $\mu$-chain) sera (Behringwerke, Marburg/Lahn, West Germany). For immunoabsorption, rabbit anti-human IgG or bovine serum albumin (A-grade, Calbiochem, San Diego, Calif.) were coupled to AH-Sepharose 4B (Pharmacia, Uppsala, Sweden) activated by glutaraldehyde (25\% aqueous solution, Serva, Heidelberg, West Germany) according to Cambiaso et al. (38). Two identical $2-\mathrm{ml}$ columns $(1 \mathrm{~cm}$ diameter) were prepared at $4^{\circ} \mathrm{C}$. They were washed with phosphate-buffered saline at pH 7.5. Clq-binding pooled gradient fractions were applied to each column, and the flow was stopped for $1 \mathrm{~h}$. Unbound gradient fraction components were washed out by slowly pumping $4 \mathrm{ml}$ of phosphatebuffered saline, pH 7.5, through each column. These effluents were concentrated to $0.5 \mathrm{ml}$ of Diaflo ultrafiltration membrane (UM 10, Amicon Corp., Lexington, Mass.) in a microfiltration system (model $8 \mathrm{MC}$, Amicon Corp.). The concentrated effluents were then tested for their Clqbinding activity. IgG contents of the Clq-binding gradient fractions used for these experiments and of the effluents were quantitated by radial immunodiffusion.

Enzymatic and chemical treatment of sera. For deoxyribonuclease (DNase) treatment, $50 \mu$ l of DNase (deoxyribonuclease 1, Worthington Biochemical Corp., N. J.) at 1 $\mathrm{mg} / \mathrm{ml}$ in Veronal-buffered saline was added to $50 \mu \mathrm{l}$ of serum. The mixture was incubated at $37^{\circ} \mathrm{C}$ for $3 \mathrm{~h}$ before the Clq-binding test was carried out. Controls were incubated with $50 \mu \mathrm{l}$ of Veronal-buffered saline alone.

For reduction and alkylation of the Clq-binding material, $100 \mu \mathrm{l}$ of serum was incubated with $100 \mu \mathrm{l}$ of 0.4 M 2-mercaptoethanol at room temperature for $1 \mathrm{~h}$ and thereafter with an additional $100 \mu \mathrm{l}$ of $0.66 \mathrm{M}$ iodoacetamide at $4^{\circ} \mathrm{C}$ for another hour. Similar serum samples were incubated with $100 \mu \mathrm{l}$ of Veronal-buffered saline. To control the reduction-alkylation procedure, $100 \mu \mathrm{l}$ of normal human serum containing human aggregated immunoglobulins at 1.5 and $0.5 \mathrm{mg} / \mathrm{ml}$ were treated in the same way as the serum samples. The mixtures were dialyzed for 24 $\mathrm{h}$ against Veronal-buffered saline before testing for Clq-binding activity.

Statistical analysis. The results were statistically evaluated by Student's $t$ test, the chi-square test, linear regression analysis, and Spearman's correlation test.

\section{RESULTS}

Clq-binding test and Raji cell radioassay in leukemic patients. The Clq-binding activity of 467 sera
TABLE I

Serum [ $\left.{ }^{125} \mathrm{I}\right]$ C1q-binding Activity in Patients with Leukemia

\begin{tabular}{|c|c|c|c|}
\hline \multirow[b]{2}{*}{ Type of leukemia } & \multirow{2}{*}{$\begin{array}{l}\text { Clq-binding } \\
\text { activity* }\end{array}$} & \multicolumn{2}{|c|}{ Incidence of elevated Clq-BAt } \\
\hline & & No. sera & No. patients \\
\hline & & $\%$ & $\%$ \\
\hline Acute myeloid & $8.9 \pm 18.6$ & $50 / 164(30.5)$ & $40 / 100(40.0)$ \\
\hline Acute lymphatic & $6.8 \pm 18.6$ & $13 / 65 \quad(20.0)$ & $9 / 39 \quad(23.1)$ \\
\hline Blastic crisis & $7.6 \pm 12.9$ & $19 / 49 \quad(38.8)$ & $13 / 28 \quad(46.4)$ \\
\hline Chronic myeloid & $0.1 \pm 3.7$ & $6 / 160$ & $5 / 38 \quad(13.2)$ \\
\hline Chronic lymphatic & $3.4 \pm 10.6$ & $7 / 29 \quad(24.1)$ & $3 / 25 \quad(12.0)$ \\
\hline Blood donors & $0.0 \pm 2.2$ & $0 / 68 \quad(0.0)$ & $0 / 68 \quad(0.0)$ \\
\hline
\end{tabular}

* Mean value of $\left[{ }^{125} \mathrm{I}\right] \mathrm{Clq}$ precipitated $\pm 1 \mathrm{SD}$.

$\ddagger$ Incidence of serum [ $\left.{ }^{125} \mathrm{I}\right] \mathrm{Clq}$-binding activity increased by more than $3 \mathrm{SD}$ values as compared with normal sera.

from 230 leukemic patients was assessed (Table I). Compared with sera from 68 healthy blood donors, the mean values of serum Clq-binding activity were significantly increased in patients with AML ( $P$ $<0.001)$, in patients with ALL $(P<0.005)$, and in patients with blastic crisis $(P<0.001)$. The mean values of serum Clq-binding activity in the patients with CML and CLL were not significantly increased ( $P$ $>0.05$ ).

Sera from 48 leukemic patients were tested for the presence of circulating immune complexes using both the Clq-binding test and the Raji cell radioassay. On a qualitative basis, the results obtained by these two techniques were in agreement in 41 of the 48 cases $(85.4 \%)$ (Fig. 1). The correlation between these

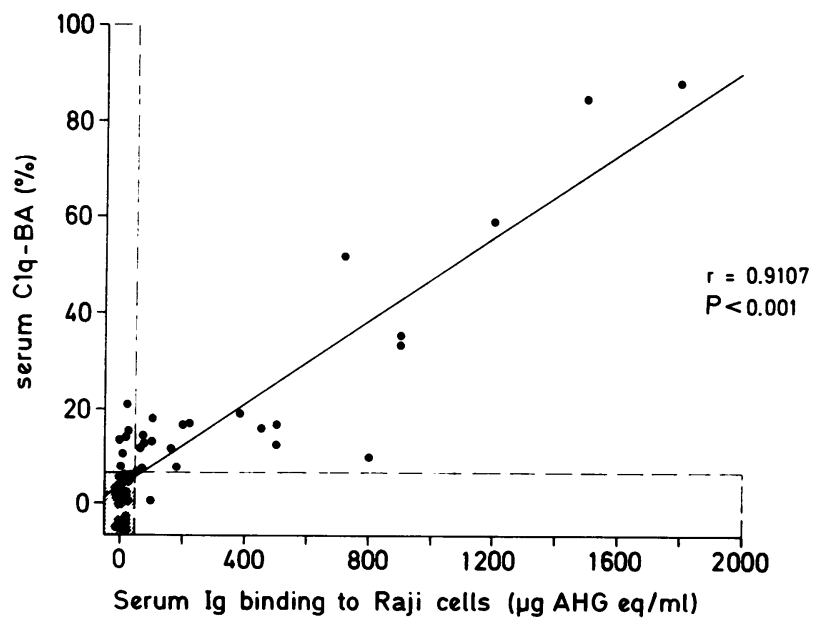

FIGURE 1 Correlation between the [ $\left.{ }^{125} \mathrm{I}\right] \mathrm{Clq}$-binding activity (Clq-BA) and the Ig binding to Raji cell in serum samples from 48 leukemic patients. The mean \pm 3 SD of [125I]Clqbinding activity and Ig binding to Raji cells of the normal sera is indicated by the shaded area. Ig binding to Raji cells is expressed as micrograms of aggregated human IgG (AHG) equivalent per milliliter of serum. 
results was also shown to be significant by linear regression analysis $(r=0.9107, P<0.001)$ and by Spearman's correlation test $(r=0.7998, P<0.001)$.

Characterization of the Clq-binding material in leukemia. To determine the size of the Clq-binding material, six sera from patients with AML, two from patients with ALL, three from patients with blastic crisis, one from a patient with CML, and three from patients with CLL were studied by ultracentrifugation analysis on $10-40 \%$ (wt/vol) sucrose density gradients.

The collected gradient fractions were tested for their Clq-binding activity. The Clq-binding material was recovered in fractions corresponding to a 10-30s molecular weight material. In gradient fractions obtained after centrifugation of normal serum, the Clqbinding activity was lower than $5 \%$. Results of serum ultracentrifugation in two patients, one with CLL and the other with blastic crisis, are represented in Fig. 2 .

In 10 patients the Clq-binding material was partially purified and concentrated using polyethylene glycol precipitation of serum before ultracentrifugation. This procedure led to a three- to fourfold increase of the Clq-binding activity in 14-28s gradient fractions when compared with the Clq-binding activity obtained in the corresponding fractions from ultracentrifugation of the original sera. Density gradient studies with the concentrated material were carried out to investigate the effect of acid treatment on the Clqbinding material. Clq-binding gradient fractions were centrifuged in parallel runs on sucrose density gradients at $\mathrm{pH} 8.3$ and $\mathrm{pH} 3.5$.

The optical density patterns of the two gradients were compared (Fig. 3). At pH 8.3, the optical density pattern showed two peaks: a small peak in the $7 s$ position and a wide, large peak in the $14-30 s$ region. The optical density pattern of the acid gradient gave a major peak in the $7 s$ situation, two smaller peaks with maximum values at the $19 \mathrm{~s}$ and $28 \mathrm{~s}$ positions, and a fourth small peak before the $7 \mathrm{~s}$ region. After neutralization of acid gradient fractions, fractions from both gradients were tested for their Clq-binding activity. Clq-binding material was still detected in 14-28s fractions from ultracentrifugation at $\mathrm{pH} \mathrm{8.3,} \mathrm{but} \mathrm{no} \mathrm{Clq-binding} \mathrm{activity} \mathrm{could} \mathrm{be} \mathrm{found}$ in any fraction from the acid gradient. By immunoelectrophoresis, IgG was shown in both the $7 s$ and 14-28s fractions at $\mathrm{pH} 8.3$, whereas at $\mathrm{pH} 3.5$, IgG was found only in the $7 s$ peak.

The presence of IgG in the Clq-binding material was further investigated by immunoabsorption. The Clq-binding fractions obtained by ultracentrifugation of sera from five leukemic patients (two AML, one ALL, and two CLL) were studied. Fractions containing the Clq-binding material were passed through columns of AH Sepharose 4B coupled either with rabbit anti-human IgG or with bovine serum
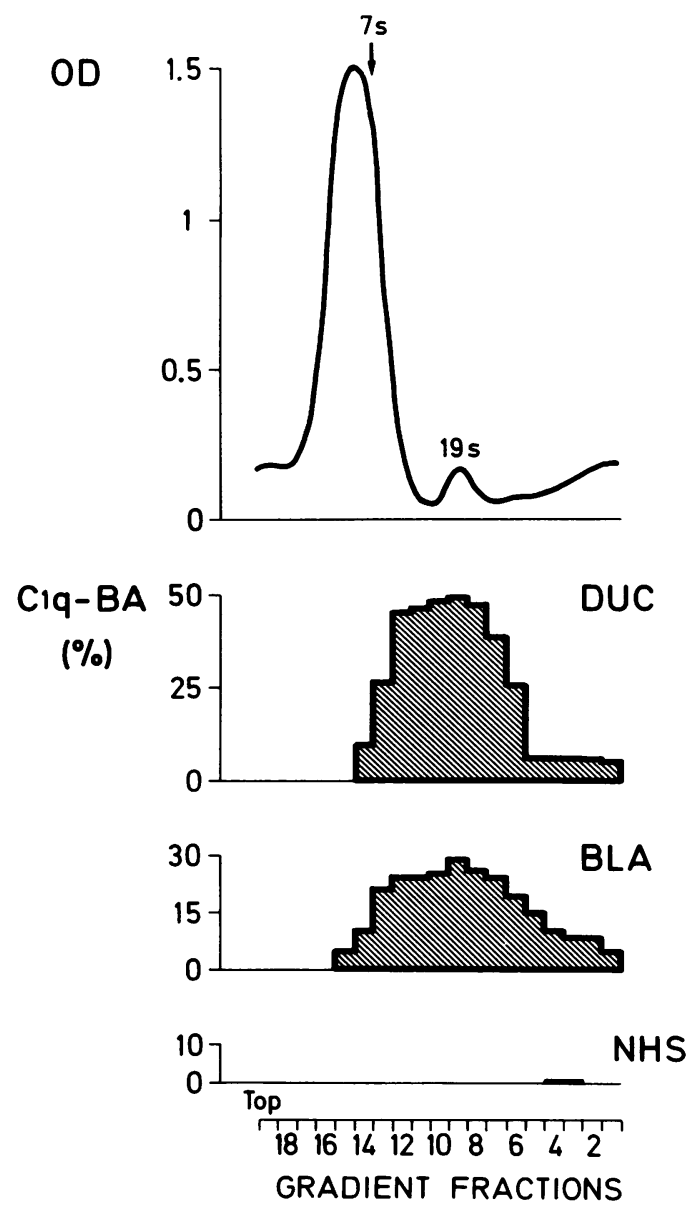

FIGURE 2 [125I]Clq-binding activity (Clq-BA) measured in each sucrose gradient fraction obtained by density fractionation of sera from a patient (DUC) with CLL, from a patient (BLA) with blastic crisis, and from a healthy blood donor (NHS). Clq-binding activity is represented by the shaded columns on the lower part of the figure. On the upper part of the figure, the optical density pattern obtained with a 1:10 diluted serum and the position of the $7 s$ and $19 s$ markers are indicated.

albumin (BSA). The Clq-binding activity of the effluents from both columns were compared. In the effluents from the anti-IgG column, only traces of Clq-binding material could be detected, whereas the Clq-binding activity of the effluents from the bovine serum albumin column was high (Table II). The passage of the Clq-binding fractions through the antiIgG-Sepharose column resulted in a parallel decrease of the IgG content and of the Clq-binding activity, respectively, to $12 \%$ and $17 \%$ of the corresponding values obtained after passage through the bovine serum albumin column.

The effect of reduction-alkylation on the Clq-binding activity of leukemic sera was assessed. Treatment of 16 serum samples with 2-mercaptoethanol and iodoacetamide led to a decrease of their Clq-binding 

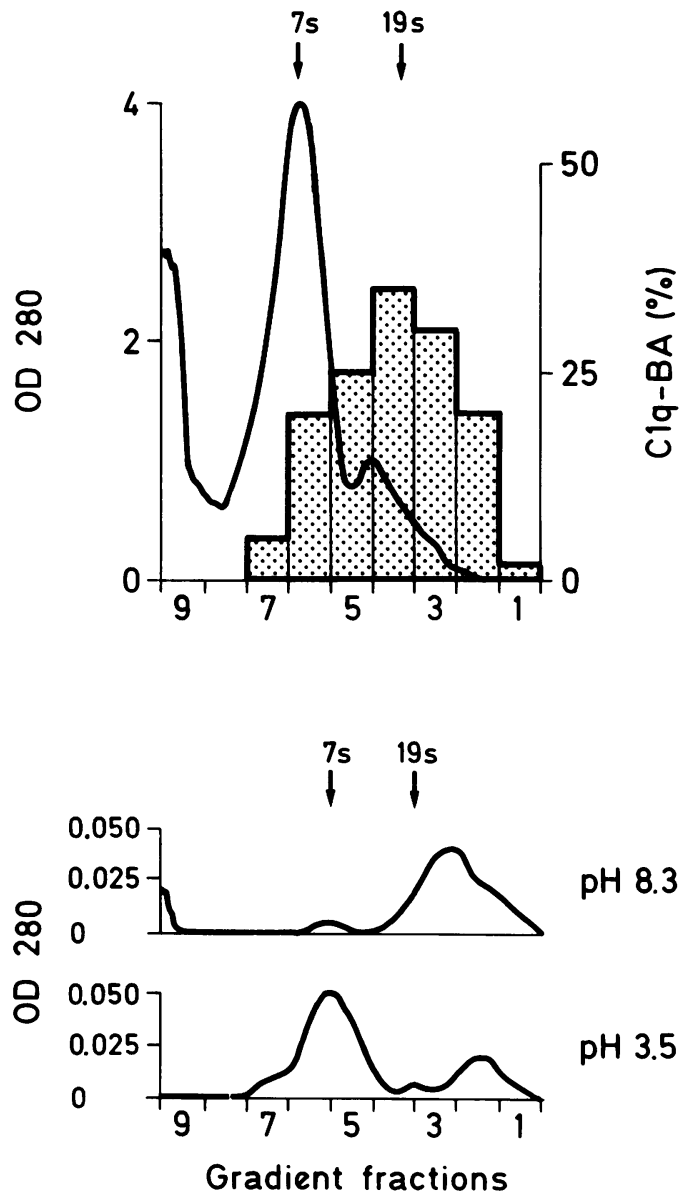

Figure 3 Acid dissociation of the Clq-binding material. On the upper part of the figure, the optical density pattern and $\left.{ }^{125} \mathrm{I}\right] \mathrm{Clq}$-binding activity (Clq-BA) of the gradient fractions, obtained after separation of $4 \%$ polyethylene glycol concentrated Clq-binding material from a patient with blastic crisis of CML, are represented; on the lower part of the figure, the curves represent the optical density pattern obtained after separation on sucrose density gradients at either $\mathrm{pH} 8.3$ or $\mathrm{pH} 3.5$ of the Clq-binding material recovered in the preceding fractions. The position of the $7 \mathrm{~s}$ and $19 s$ markers are indicated on the figure. activity from $16 \pm 9 \%$ to $4 \pm 8 \% \quad(P<0.001)$. Similar effect was found after reduction-alkylation of aggregated human immunoglobulin used as control samples.

To find whether the Clq-binding material contained DNA, 12 positive sera were incubated with either DNase or buffer as control. The treatment with DNase did not reduce the Clq-binding activity (mean Clq-binding activity of sera: without DNase treatment $=27.4 \pm 16.6 \%$; with DNase treatment $=26.6 \pm 17.2 \%$ ).

Correlation between serum C1q-binding activity and the stage of leukemia. The serum Clq-binding activity was compared in two groups of patients: those with acute leukemia whose disease was in the blastic stage and those in whom complete remission had been achieved. The group mean values of serum Clq binding were significantly higher in patients during the blastic stage of leukemia than during complete remission (13 vs. $3.2 \%, P<0.005$ in AML; 11.0 vs. $0.6 \%, P<0.01$ in $\mathrm{ALL} ; 9.3$ vs. $0.0 \%, P$ $<0.001$ in blastic crisis). An increased serum Clq-binding activity was also found more frequently in patients tested during the acute stage: respectively, in $45.6 \%(n=79), 36 \%(n=25)$, and $50 \%(n=26)$ of patients with acute phase of AML, ALL, or blastic crisis as compared with $12.2 \%(n=41), 4.8 \%$ ( $n$ $=21)$, and $0.0 \%(n=6)$ of corresponding patients in remission. In 27 patients studied for a period of several months, the elevated serum Clq binding was clearly associated with the blastic phase of the disease (Fig. 4). In 13 patients with ALL, AML, or blastic crisis, a high serum Clq-binding activity was found during the blastic stage but disappeared during the remission. In 10 patients the serum Clqbinding activity was normal during remission, and later became positive at the time of relapse. In six cases of CML, the previously normal serum Clq binding became increased during blastic crises.

Correlation of serum C1q-binding activity with hematological parameters, sepsis, and therapy. The $\mathrm{Clq}$ binding observed in individual serum samples

TABLE II

Removal of C1q-binding Material on Anti-Ig Immunoabsorbant

\begin{tabular}{|c|c|c|c|c|c|c|c|}
\hline \multirow[b]{2}{*}{$\begin{array}{l}\text { Patient } \\
\text { no. }\end{array}$} & \multirow[b]{2}{*}{$\begin{array}{l}\text { Type of } \\
\text { leukemia }\end{array}$} & \multicolumn{3}{|c|}{ Clq-binding activity* } & \multicolumn{3}{|c|}{ IgG content } \\
\hline & & $\begin{array}{l}\text { Sample applied } \\
\text { on column }\end{array}$ & $\begin{array}{c}\text { Effluent of } \\
\text { BSA-Sepharose }\end{array}$ & $\begin{array}{l}\text { Effluent of } \\
\text { anti-IgG-Sepharose }\end{array}$ & $\begin{array}{l}\text { Sample applied } \\
\text { on column }\end{array}$ & $\begin{array}{c}\text { Effluent of } \\
\text { BSA-Sepharose }\end{array}$ & $\begin{array}{c}\text { Effluent of } \\
\text { anti-IgG-Sepharose }\end{array}$ \\
\hline & & & & & & $\mu g$ & \\
\hline 1 & AML & 35 & 27.2 & 4.3 & 210 & 110 & 20 \\
\hline 2 & AML & 27 & 17.9 & 2.2 & 290 & 180 & 16 \\
\hline 3 & ALL & 45 & 21.3 & 6.6 & 150 & 110 & 20 \\
\hline 4 & CLL & 64 & 56.8 & 7.9 & 250 & 200 & 14 \\
\hline 5 & CLL & 51 & 47.3 & 6.2 & 120 & 110 & 7 \\
\hline \multicolumn{2}{|c|}{ Mean \pm 1 SD } & $44 \pm 14.3$ & $34.1 \pm 17.1$ & $5.4 \pm 2.2$ & $204 \pm 70$ & $140 \pm 40$ & $15 \pm 5$ \\
\hline
\end{tabular}

*\% [125I]Clq precipitated.

878 Carpentier, Lange, Fiere, Fournie, Lambert, and Miescher 


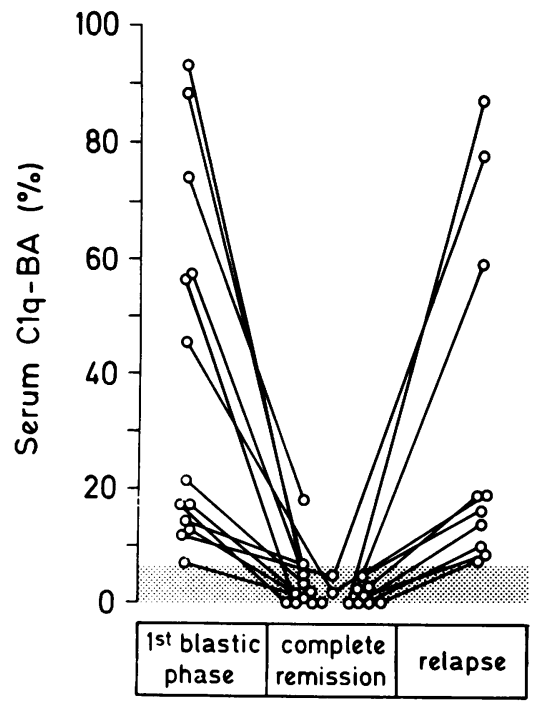

acute leukemia

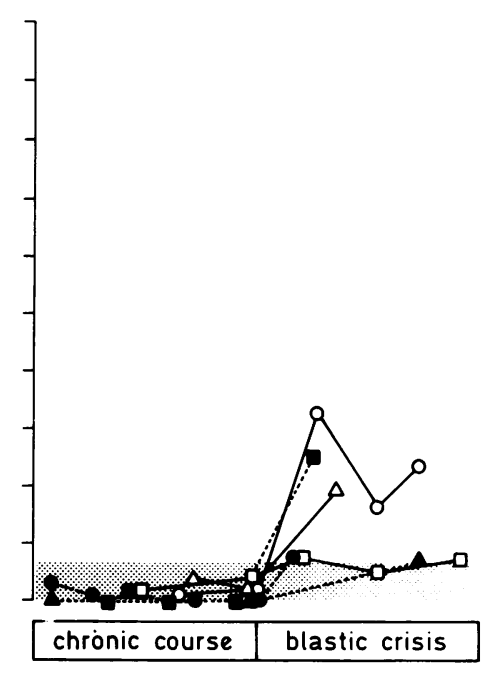

CML

FIGURE 4 Evolution of the serum [ $\left.{ }^{125} \mathrm{I}\right] \mathrm{Clq}$-binding activity (Clq-BA) in 27 patients with leukemia according to the stage of leukemia. At the left, serum Clq-binding activity of 21 patients with AML, ALL, or blastic crisis; at the right, serum Clq-binding activity in 6 patients with CML who developed blastic crisis.

was not related to the white blood cell count or the hemoglobin or platelet levels. During the acute stage of the disease, no correlation was found between the serum-Clq binding activity and the presence of sepsis in the patients at the time of collection of the serum. A high Clq-binding activity was demonstrated in $45.5 \%$ of the serum samples from patients with sepsis and in $40.4 \%$ of those from patients without evidence of such complication. Similar results were observed when comparing the serum Clq-binding activity with the erythrocyte sedimentation rate (ESR); $37.2 \%$ of sera from patients with an increased ESR and $48.2 \%$ of sera from cases with a normal ESR had an elevated Clq binding.

The serum Clq-binding activity of the 130 patients studied during the blastic stage of leukemia were compared, using as a criterion the fact that they had received chemotherapy or had not yet been treated. The mean Clq-binding activity ( \pm 1 SD) of 62 serum samples drawn before treatment reached $19.4( \pm 25.5) \%$, while that of the 113 samples collected after initiation of chemotherapy was $6.8( \pm 14.8) \%$. The difference between these mean values was significant $(P<0.001)$. The incidence of an increased serum Clq-binding activity was also significantly higher $(P<0.005)$ in the untreated patients; $58.1 \%$ of sera from untreated patients were positive as compared with $33.6 \%$ of sera in the treated patients.

Sera from 30 leukemic patients, which had been tested for their Clq-binding activity, were also investigated for the presence of multispecific anti-HLA antibodies. Anti-HLA antibodies were detected in 10 cases: 5 out of 15 with elevated serum Clq-binding activity, and 5 out of 15 with Clq binding within normal range. There was no difference in the levels of antibody found in these groups.

Circulating immune complexes and prognosis in acute leukemia. The presence of circulating immune complexes in acute leukemia was studied retrospectively in relation to the clinical course in individual patients. Follow-up data were obtained for the 130 patients tested during the acute stage: 110 at the onset of the disease and 20 in relapse. Incidence of response to therapy was assessed in these patients. The remission rate was significantly higher in the 61 patients with serum Clq-binding activity within the normal range at the onset of the leukemia than in the 49 patients with circulating immune complexes during this period $(P<0.005$ in AML, $P<0.01$ in ALL, and $P<0.05$ in blastic crisis) (Table III); $75.4 \%$ of the former group of patients experienced a complete or partial remission, while only $32.7 \%$ of the latter group went into remission. The difference between those two groups was highly significant $(P<0.0005)$. The other patients did not respond to therapy and died during the blastic stage. In the 20 patients tested during relapse, only 2 out of 11 with serum Clq-binding within the normal range entered into remission.

The prognostic significance of circulating immune complexes at the onset of acute leukemia was also studied in relation to known features of prognostic relevance: sex, age, white blood cell count, hemoglobin and platelet levels, extent of marrow infiltration, and 
TABLE III

Serum [125I ]Clq-binding Activity at the Onset of Acute Leukemia and Incidence of Remission

\begin{tabular}{lrcccccr}
\hline & \multicolumn{3}{c}{ Patients with elevated Clq-BA* } & & \multicolumn{2}{c}{ Patients with Clq-BA within normal range } \\
\cline { 2 - 6 } Type of leukemia & No. & Complete remission & Partial remission & & No. & Complete remission & Partial remission \\
\hline Acute myeloid & 30 & $9(30.0 \%)$ & $1(3.3 \%)$ & & 37 & $24(64.9 \%)$ & $2(5.4 \%)$ \\
Acute lymphatic & 8 & $3(37.5 \%)$ & $0(0.0 \%)$ & & 13 & $12(92.3 \%)$ & $0(0.0 \%)$ \\
Blastic crisis & 11 & $1(9.1 \%)$ & $2(18.2 \%)$ & & 11 & $4(36.4 \%)$ & $4(36.4 \%)$ \\
$\quad$ Total & 49 & $13(26.5 \%)$ & $3(6.1 \%)$ & & 61 & $40(65.6 \%)$ & $6(9.8 \%)$ \\
\hline
\end{tabular}

* Serum Clq-binding activity increased by more than $3 \mathrm{SD}$ values as compared with normal sera.

presence of sepsis (Table IV). The group with and the group without circulating immune complexes had similar sex and age distribution. In AML and ALL, analysis of response rate in patients separated into age groups revealed progressively poorer remission incidence with increasing age, regardless of whether or not the patients had circulating immune complexes during the blastic stage (Fig. 5). Age and the presence of circulating immune complexes appeared as two independent prognostic features which could be combined for the assessment of the prognosis (Table V).

The response to therapy of the patients with circulating immune complexes was not related to unfavorable hematologic parameters (Table IV): white blood cell count below 2,000 per $\mathrm{mm}^{3}$ or above 50,000 per $\mathrm{mm}^{3}$, hemoglobin level less than $7 \mathrm{~g} /$ $100 \mathrm{ml}$, and platelet level under 100,000 per $\mathrm{mm}^{3}$. The degree of marrow infiltration by leukemic cells did not differ significantly between the patients with or without circulating immune complexes, except in the patients with ALL who responded to treatment. In the present study, the cytological variety of AML did not appear to influence the response rate observed in these patients. The patient group without circulating immune complexes included 32 patients with acute myeloblastic leukemia, 2 patients with acute myelomonocytic leukemia, and 3 patients with acute promyelocytic leukemia. In the patients with detectable circulating immune complexes, 26 had acute myeloblastic leukemia and 4 had acute myelomonocytic leukemia. Incidence of sepsis was almost the same in the patients with immune complexes and those with serum Clq-binding activity in the normal range (Table IV). In patients without detectable immune complexes, presence of sepsis and bone marrow infiltration by leukemic cells above $75 \%$ at onset of leukemia were associated with a poorer response rate.

The individual survival times within the study period of the patients tested at the onset of disease were assessed (Fig. 6). The median survival time was $5 \mathrm{mo}$ in patients with AML, more than 18 mo in the patients with ALL, and 5 mo in the pa-

TABLE IV

Circulating Immune Complexes and Prognostic Factors in Acute Leukemia

\begin{tabular}{|c|c|c|c|c|c|c|c|c|c|c|c|c|c|c|c|c|c|c|}
\hline & \multirow{2}{*}{\multicolumn{2}{|c|}{$\begin{array}{c}\text { No. of } \\
\text { patients }\end{array}$}} & \multirow{2}{*}{\multicolumn{2}{|c|}{$\begin{array}{c}\text { Sex } \\
(\mathrm{M} / \mathrm{F})\end{array}$}} & \multirow{2}{*}{\multicolumn{2}{|c|}{ Mean age \pm 1 SD }} & \multirow{2}{*}{\multicolumn{2}{|c|}{$\begin{array}{c}\text { WBC }^{*} \\
\leqslant 2 \times 10^{3} \\
\text { or } \\
\geqslant 50 \times 10^{3} \\
\text { per } \mathrm{mm}^{3}\end{array}$}} & \multirow{2}{*}{\multicolumn{2}{|c|}{$\begin{array}{c}\begin{array}{c}\text { Hemo- } \\
\text { globin } \\
\text { level }\end{array} \\
\leqslant 7 \mathrm{~g} / 100 \mathrm{ml}\end{array}$}} & \multirow{2}{*}{\multicolumn{2}{|c|}{$\begin{array}{c}\text { Platelets } \\
<100 \times 10^{3} \\
\text { per } \mathrm{mm}^{3}\end{array}$}} & \multicolumn{4}{|c|}{$\begin{array}{c}\text { Extent of marrow infiltration } \\
\text { by leukemic cells }\end{array}$} & \multirow{2}{*}{\multicolumn{2}{|c|}{$\begin{array}{c}\text { Incidence } \\
\text { of sepsis }\end{array}$}} \\
\hline & & & & & & & & & & & & & \multicolumn{2}{|c|}{ Mean \pm 1 SD } & \multicolumn{2}{|c|}{$\geqslant 75 \%$} & & \\
\hline & IC+ & IC- & IC+ & IC- & IC+ & IC- & IC+ & IC- & IC+ & IC- & IC+ & IC- & IC+ & IC- & IC+ & IC- & IC+ & IC- \\
\hline & & & & & \multicolumn{2}{|c|}{$y r$} & \multicolumn{2}{|c|}{$\%$} & \multicolumn{2}{|c|}{$\%$} & \multicolumn{2}{|c|}{$\%$} & \multicolumn{2}{|c|}{$\%$} & \multicolumn{2}{|c|}{$\%$} & \multicolumn{2}{|c|}{$\%$} \\
\hline AML & 30 & 37 & $17 / 13$ & $18 / 19$ & $48.5 \pm 19.4$ & $52.0 \pm 18.3$ & 30 & 46 & 13 & 16 & 80 & 65 & $72 \pm 21$ & $62 \pm 22$ & 60 & 35 & 40 & 46 \\
\hline Responders $\ddagger$ & 10 & 26 & $5 / 5$ & $13 / 13$ & $36.6 \pm 17.7$ & $46.2 \pm 17.8$ & 20 & 46 & 20 & 15 & 80 & 62 & $74 \pm 21$ & $58 \pm 21$ & 60 & 27 & 40 & 38 \\
\hline Nonresponders $\S$ & 20 & 11 & $12 / 8$ & $5 / 6$ & $54.6 \pm 16.1$ & $65.8 \pm 11.1$ & 35 & 45 & 10 & 18 & 80 & 73 & $71 \pm 22$ & $70 \pm 22$ & 60 & 55 & 40 & 64 \\
\hline ALL & 8 & 13 & $5 / 3$ & $7 / 6$ & $25.1 \pm 12.2$ & $24.3 \pm 15.1$ & 38 & 46 & 0 & 8 & 75 & 54 & $89 \pm 10$ & $72 \pm 21$ & 88 & 62 & 25 & 23 \\
\hline Responders & 3 & 12 & $1 / 2$ & $7 / 5$ & $15.0 \pm 9.0$ & $21.3 \pm 10.8$ & 0 & 42 & 0 & 0 & 67 & 50 & $88 \pm 8$ & $70 \pm 21$ & 100 & 58 & 33 & 17 \\
\hline Nonresponders & $\mathbf{5}$ & 1 & $4 / 1$ & $0 / 1$ & $31.2 \pm 9.8$ & 61.0 & 60 & $1 / 1$ & 0 & $1 / 1$ & 80 & $1 / 1$ & $90 \pm 11$ & 95 & 80 & $1 / 1$ & 20 & $1 / 1$ \\
\hline BC & 11 & 11 & $7 / 4$ & $7 / 4$ & $45.7 \pm 13.7$ & $48.6 \pm 11.9$ & 9 & 9 & 18 & 18 & 45 & 64 & $50 \pm 20$ & $49 \pm 19$ & 9 & 9 & 36 & 27 \\
\hline Responders & 3 & 8 & $3 / 0$ & $5 / 3$ & $45.1 \pm 12.8$ & $47.9 \pm 11.9$ & 0 & 13 & 0 & 13 & 0 & $\mathbf{5 0}$ & $56 \pm 11$ & $50 \pm 21$ & $\mathbf{0}$ & 13 & 33 & 13 \\
\hline Nonresponders & 8 & 3 & $4 / 4$ & $2 / 1$ & $47.3 \pm 19.1$ & $50.7 \pm 14.4$ & 13 & $\mathbf{0}$ & 25 & 33 & 63 & 100 & $48 \pm 23$ & $47 \pm 11$ & 13 & 0 & 38 & 67 \\
\hline
\end{tabular}

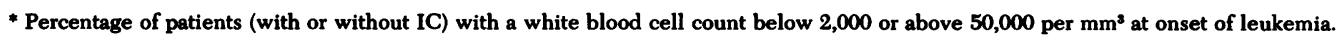

t Patients with (IC+) or without (IC-) circulating immune complexes at onset of acute leukemia and who entered into remission.

$\$$ Patients with or without circulating immune complexes at onset of acute leukemia and who did not respond to therapy. 

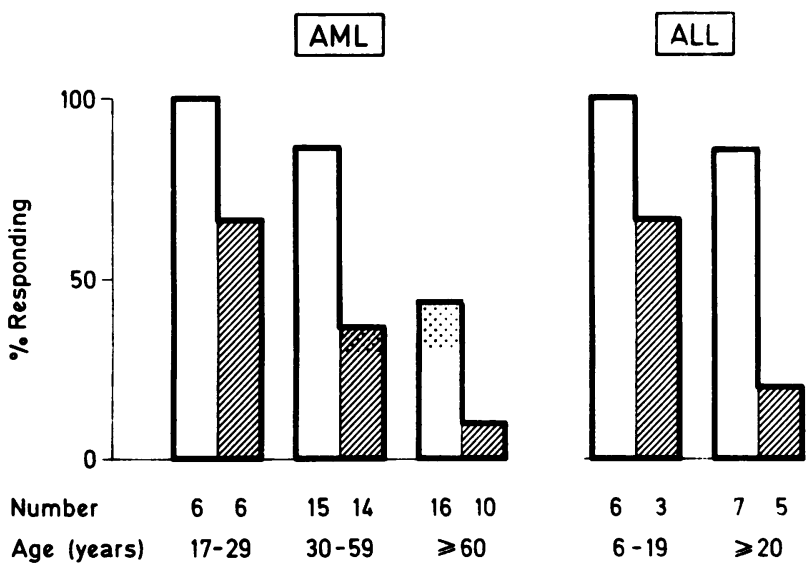

FIGURE 5 The response rates in relation to the presence of immune complexes in various age groups of patients with AML (left side) or ALL (right side). Patients with detectable circulating immune complexes at onset of leukemia are represented by the shaded columns and those without such complexes by the plain columns. In each column, the dotted areas indicate the proportion of patients in whom the response to treatment was limited to partial remission.

tients with blastic crisis. The survival of these patients was further considered according to the level of their serum Clq-binding activity during the acute stage. In the patients with serum Clq-binding activity within the normal range, the median survival time was more than $18 \mathrm{mo}$ in AML and ALL and more than $8 \frac{1}{2}$ mo in blastic crisis. The corresponding median survival times in the patients with elevated serum Clq-binding activity were much lower: 64 days in AML, 135 days in ALL, and 90 days in blastic crisis. For the patients with AML followed during 6 mo, survival rate at this time was $21 / 35(60 \%)$ in those without detectable immune complexes and 7/30 $(23 \%)$ in those with circulating immune complexes $(P<0.005)$. In the relapsing patients, the survival times from the onset of relapse were short and bore no

TABLE V

Combined Prognostic Value of Age and Circulating Immune Complexes in Patients with AML

\begin{tabular}{lrrrrrr}
\hline & \multicolumn{4}{c}{ Incidence of complete remission } \\
\cline { 2 - 7 } \multicolumn{1}{c}{ Patients } & \multicolumn{1}{c}{ Total } & \multicolumn{1}{c}{$\begin{array}{c}\text { Patients } \\
\text { with IC }\end{array}$} & $\begin{array}{c}\text { Patients } \\
\text { without IC* }\end{array}$ \\
\hline & no. & $\%$ & no. & $\%$ & no. & $\%$ \\
All patients & $33 / 67$ & $(49)$ & $9 / 30$ & $(30)$ & $24 / 37$ & $(65)$ \\
More than 60 years old & $6 / 26$ & $(23)$ & $1 / 10$ & $(10)$ & $5 / 16$ & $(31)$ \\
Less than 60 years old & $27 / 41$ & $(66)$ & $8 / 20$ & $(40)$ & $19 / 21$ & $(90)$
\end{tabular}

* Patients with or without circulating immune complexes (IC) at the onset of acute leukemia and who achieved a complete remission.
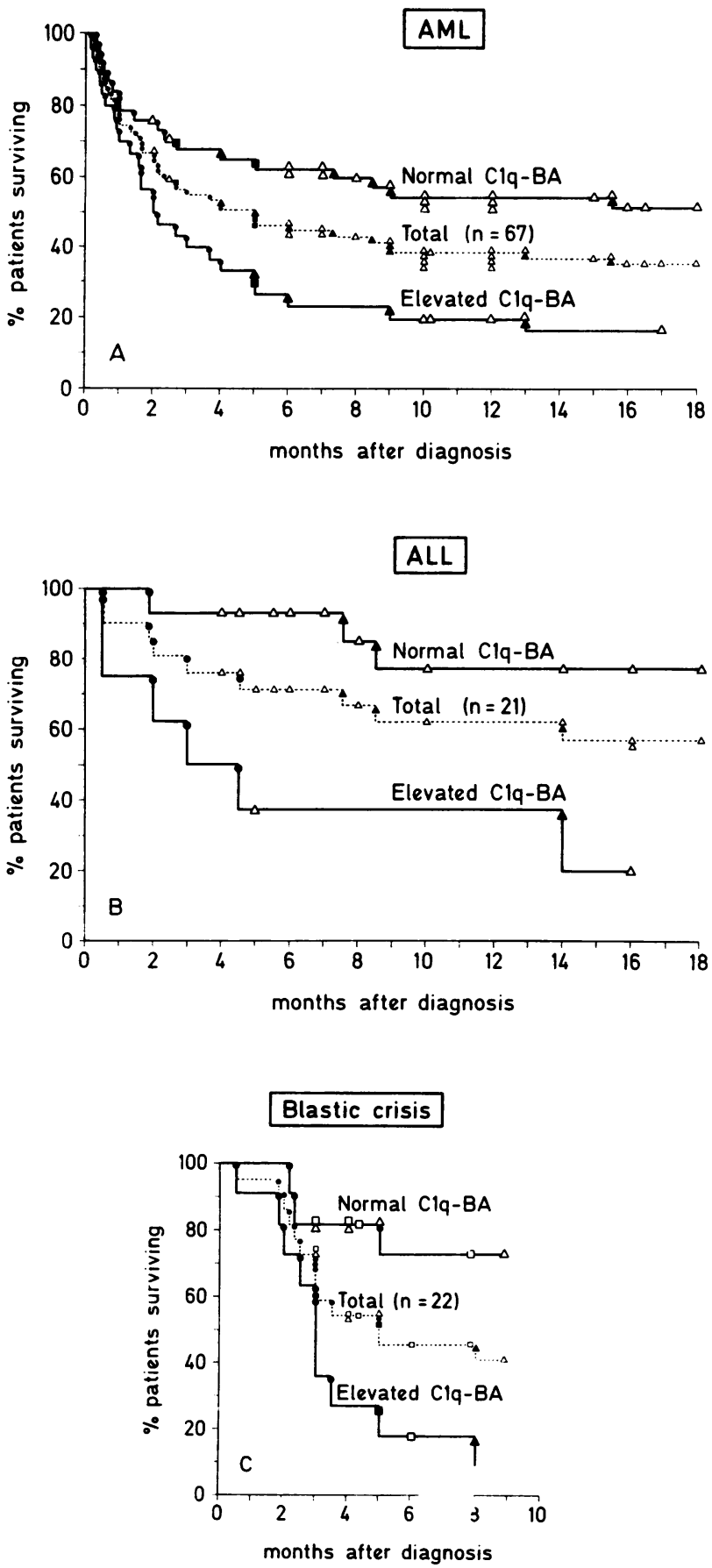

FIGURE 6 Graphical representation of individual survival to date of (A) 67 patients with AML, (B) 21 patients with ALL, and (C) 22 patients with blastic crisis of CML, according to their serum $\mathrm{Clq}$-binding activity $(\mathrm{Clq}-\mathrm{BA})$ during the blastic stage of acute leukemia. Each point corresponds to one patient. $\Delta=$ patient who continues in complete remission; $\square=$ patient who continues in incomplete remission; $\Delta$ = patient who relapsed and died after achieved complete remission; = patient who died during attempt of remission induction; $\mathbf{\square}=$ patient who died during incomplete remission. 
relation to the serum Clq-binding activity of the patients. The time interval between diagnosis and the serum sampling was short and did not influence these findings.

\section{DISCUSSION}

The occurrence of circulating immune complexes in cancer patients has been suggested first by the demonstration of serum blocking factors possibly related to immune complexes, and secondly by the direct detection of material similar to antigenantibody complexes in some patients with various types of malignancy $(18,20-28,39)$. In human leukemia, the presence of immune complexes has been suggested by the finding of renal glomerular deposits of Ig and complement in a few cases (29). Serological studies using methods for direct detection of immune complexes have so far been limited (18, 23, 24, 27).

The present data indicate that a material involving Ig and C3, and capable of reacting with $\mathrm{Clq}$, may be present in relatively large amounts in the serum from many patients with acute leukemia. Physicochemical properties of this material indicate also that it may consist of circulating immune complexes. In density gradient experiments, the material sedimented as a 14-28s macromolecule, acid dissociation of which led to the appearance of a $7 \mathrm{~s}$ peak containing IgG. Removal of IgG from the material either by immunoabsorption or by acid dissociation, or alteration of serum Ig molecules by a mild reduction-alkylation treatment, abolished the ability of the material to bind Clq. The possibility that some unknown polyanionic substances account for the serum Clq binding of some leukemic patients cannot be rules out. Interference of DNA in the present results was excluded, however, by the DNase treatment of the serum samples, and that of endotoxins or Creactive protein complexes by the test conditions.

The fact that the immune complexes were found mostly in sera from patients at the blastic stage of leukemia, regardless of the type of acute leukemia, should be considered in relation to the nature of antigens possibly involved in the complexes. The lack of correlation between the presence of immune complexes and evident sepsis in the patients minimizes the possibility of a bacterial origin of the complexed antigen. Clinically inapparent bacterial infections or slow virus infections may account, however, for formation of bacterial or viral antigen-antibody complexes. Thus, the course of the infection would be closely associated with the blastic stage of the leukemia, with a rapid disappearance during complete remission. Antibodies reacting with the major histocompatibility antigens, possibly induced by repeated blood transfusion, do not appear to be a major source of circulating immune complexes in leukemia. Antigens with a specificity unrelated to the leukemic cells, or related to the blastic state of the cells, may be considered. DNA anti-DNA (40) or Ig antiIg (41-43) complexes, as well as nuclear antigen(s) (expressed in proliferating cells and capable of inducing specific antibodies), have been demonstrated, especially in leukemia (44-46). Correlation between the presence in serum of immune complexes and the blastic cell proliferation is also in agreement with a possible involvement of leukemia-associated antigens $(5-13,47)$. However, the destruction of many malignant cells by chemotherapy does not increase the level of circulating immune complexes.

The clinical relevance of circulating immune complexes in patients with leukemia is still difficult to assess. These complexes may be a secondary phenomenon of the disease particularly associated with the most severe forms of leukemia. The occurrence and persistence of circulating immune complexes in some patients with acute leukemia may also reflect a particular immune status of these patients $(48,11)$, since the persistence of antigen-antibody complexes may be favored by the production of antibodies of low avidity (49) or of low titer (50). However, circulating immune complexes may favor the progression of leukemia by modulating the immune response of the host against the malignant cells. Indeed, antigenantibody complexes can enhance or suppress lymphocyte activation (51-54) and modulate functions of B lymphocytes (55) or T lymphocytes (56-62). In animals bearing growing tumors, at least some of the serum blocking factors consist of immune complexes (1517).

The present data show that patients with acute leukemia and circulating immune complexes have a worse prognosis than those without such complexes. It is proposed that the assessment of the prognosis in patients with acute leukemia would be improved by the determination of this new parameter in combination with some other classical prognostic factors (63), such as the age of the patients.

\section{ACKNOWLEDGMENTS}

We thank Dr. J. E. Sokal (Roswell Park Memorial Institute, Buffalo, N. Y.; Dr. J. Monnier, Dr. J. Pris, and Dr. B. Cassagneau (Centre hospitalier regional, Toulouse, France); Dr. J. Hugues and Dr. C. Nizet (Hopital Universitaire, Liège, Belgium); and Dr. M. Wyss, Dr. G. Boreux, and Dr. J. F. Babel (Hopital Cantonal, Geneva, Switzerland) who provided experimental sera as well as clinical and laboratory data. We are indebted to Dr. M. Jeannet (Hopital Cantonal, Geneva, Switzerland) who determined anti-HLA antibodies. We are grateful to Dr. L. J. Mackey and Dr. S. Izui for reviewing this manuscript and to Mrs. J. Ringrose and Mrs. M. Devouge for their excellent secretarial assistance.

This work was supported by the World Health Organiza- 
tion, the Swiss National Research Foundation (grant 3.260.74), and the Dubois-Ferrière-Dinu Lipatti Foundation.

\section{REFERENCES}

1. Hellstrom, I., K. E. Hellstrom, G. E. Pierce, and J. P. S. Yang. 1968. Cellular and humoral immunity to different types of human neoplasms. Nature (Lond.). 220: 13521354.

2. Klein, G. 1971. Immunological studies on human tumors. Dilemmas of the experimentalist. Isr. J. Med. Sci. 7: 111-131.

3. Irie, K., R. F. Irie, and D. L. Morton. 1974. Evidence for in vivo reaction of antibody and complement to surface antigens of human cancer cells. Science (Wash. D. C.). 186: 454-456.

4. Heberman, R. B. 1974. Delayed hypersensitivity skin reactions to antigens on human tumors. Cancer. 34: 1469-1473.

5. Mann, D. L., R. Halterman, and B. Leventhal. 1974. Acute leukemia-associated antigens. Cancer. 34: 1446-1451.

6. Baker, M. A., K. Ramachandar, and R. N. Taub. 1974. Specificity of heteroantisera to human acute leukemiaassociated antigens. J. Clin. Invest. 54: 1273-1278.

7. Mohanakumar, T., R. S. Metzgar, and D. S. Miller. 1974. Human leukemia cell antigens: serologic characterization with xenoantisera. J. Natl. Cancer Inst. 52: 1435-1444.

8. Brown, G., D. Capellaro, and M. Greaves. 1975. Leukemia-associated antigens in man. J. Natl. Cancer Inst. 55: 1281-1289.

9. Harris, R. 1973. Leukemia antigens and immunity in man. Nature (Lond.) 241: 95-100.

10. Hersey, P., I. C. M. MacLennan, A. C. Campbell, R. Harris, and C. B. Freeman. 1973. I. Demonstration of antibody-dependent lymphocyte killing of human allogeneic myeloblasts. Clin. Exp. Immunol. 14: 159-166.

11. Gutterman, J. V., R. D. Rossen, W. T. Butler, K. B. McCredie, G. P. Bodey, Sr., E. J. Freireich, and E. M. Hersh. 1973. Immunoglobulin on tumor cells and tumorinduced lymphocyte blastogenesis in human acute leukemia. N. Engl. J. Med. 288: 169-175.

12. Fefer, A., E. Mickelson, and E. D. Thomas. 1974. Leukaemia antigens: mixed leukocyte culture tests on twelve leukaemic patients with identical twins. Clin. Exp. Immunol. 18: 237-242.

13. Metzgar, R. S., T. Mohanakumar, and D. S. Miller. 1975. Membrane-bound immunoglobulins on human leukemic cells. J. Clin. Invest. 56: 331-338.

14. Hellstrom, I., H. O. Sjogren, G. A. Warner, and K. E. Hellstrom. 1971. Blocking of cell-mediated immunity by sera from patients with growing neoplasms. Int.J. Cancer. 7: 226-227.

15. Baldwin, R. W., M. J. Embleton, M. R. Price, and R. A. Robins. 1974. Immunity in the tumor-bearing host and its modification by serum factors. Cancer. 34: 14521460.

16. Sjogren, H. O., I. Hellstrom, S. C. Bansal, and K. E. Hellstrom. 1971. Suggestive evidence that the "blocking antibodies" of tumor-bearing individuals may be antigenantibody complexes. Proc. Natl. Acad. Sci. U. S. A. 68: $1372-1375$.

17. Baldwin, R. W., M. R. Price, and R. A. Robins. 1972. Blocking of lymphocyte-mediated cytotoxicity for rat hepatoma cells by tumour-specific antigen-antibody complexes. Nat. New Biol. 238: 185-187.

18. Jose, D. G., and R. Seshadri. 1974. Circulating immune complexes in human neuroblastoma: direct assay and role in blocking specific cellular immunity. Int. J. Cancer. 13: 824-838.

19. Mantovani, A., and F. Spreafico. 1975. On the nature of blocking factors and their lymphoid target cells in an allogeneic tumor system. Eur. J. Cancer. 11: 451-455.

20. Ludwig, F. J., and C. L. Cusumano. 1974. Detection of immune complexes using ${ }^{125}$ I goat anti (human IgG) monovalent (Fab) antibody fragments. J. Natl. Cancer Inst. 52: 1529-1536.

21. Amlot, P. L., J. M. Slaney, and B. D. Williams. 1976. Circulating immune complexes and symptoms in Hodgkin's disease. Lancet. 1: 449-451.

22. Kavai, M., E. Berényi, E. Palkovi, and Gy. Szegedi. 1976. Immune complexes in Hodgkin's disease. Lancet. I: 1249-1250.

23. Theofilopoulos, A. N., C. B. Wilson, and F. J. Dixon. 1976. The Raji cell radioimmunoassay for detecting immune complexes in human sera. J. Clin. Invest. 57: 169-182.

24. Heimer, R., and G. Klein. 1976. Circulating immune complexes in sera of patients with Burkitt's lymphoma and nasopharyngeal carcinoma. Int. J. Cancer. 18: 310316.

25. Constanza, M. E., V. Pinn, R. S. Schwartz, and L. Nathanson. 1973. Carcinoembryonic antigen-antibody complexes in a patient with colonic carcinoma and nephrotic syndrome. N. Engl. J. Med. 289: 520-523.

26. Sutherland, J. C., R. V. Markham, Jr., H. E. Ramsey, and M. R. Mardiney, Jr. 1974. Subclinical immune complex nephritis in patients with Hodgkin's disease. Cancer Res. 34: 1179-1181.

27. Oldstone, M. B. A., A. N. Theofilopoulos, G. Klein, and P. Guven. 1975. Immune complexes associated with neoplasia: presence of Epstein-Barr virus antigenantibody complexes in Burkitt's lymphoma. Intervirology. 4: 292-302.

28. Pascal, R. R., P. M. Iannacone, F. M. Rollwagen, T. A. Harding, and S. J. Bennett. 1976. Electron microscopy and immunofluorescence of glomerular immune complex deposits in cancer patients. Cancer Res. 36: 43-47.

29. Sutherland, J. C., and M. R. Mardiney, Jr. 1973. Immune complex disease in the kidneys of lymphoma-leukemia patients: the presence of an oncornavirus-related antigen. J. Natl. Cancer Inst. 50: 633-639.

30. Zubler, R. H., G. Lange, P. H. Lambert, and P. A. Miescher. 1976. Detection of immune complexes in unheated sera by a modified ${ }^{125} \mathrm{I}-\mathrm{Clq}$ binding test. $J$. Immunol. 116: 232-235.

31. Sokal, J. E., C. W. Aungst, and J. T. Grace, Jr. 1973. Immunotherapy in well-controlled chronic myelocytic leukemia. N. Y. State J. Med. 73: 1180-1185.

32. Volanakis, J. E., and R. M. Stroud. 1972. Rabbit Clq: purification, functional and structural studies. J. Immunol. Methods. 2: 25-34.

33. Heusser, C., M. Boesman, J. H. Nordin, and H. Isliker. 1973. Effect of chemical and enzymatic radioiodination on in vitro human Clq activities. J. Immunol. 110: 820-828.

34. Mahieu, P., P. H. Lambert, and P. A. Miescher. 1974. Detection of antiglomerular basement membrane antibodies by a radioimmunological technique. Clinical application in human nephropathies. J. Clin. Invest. 54: 128-137.

35. Theofilopoulos, A. N., F. J. Dixon, V. A. Bokisch. 1974. Binding of soluble immune complexes to human lymphoblastoid cells. I. Characterization of receptors for IgG Fc and complement and description of the binding mechanism. J. Exp. Med. 140: 877-894. 
36. Martin, R. G., and B. N. Ames. 1961. A method for determining the sedimentation behavior of enzymes: application to protein mixtures. J. Biol. Chem. 236: 1372-1379.

37. Scheidegger, J. J. 1955. Une micro-méthode de l-immunoélectrophorèse. Int. Arch. Allergy Appl. Immunol. 7: $103-110$.

38. Cambiaso, C. L., A. Goffinet, J. P. Vaerman, and J. T. Heremans. 1975. Glutaraldehyde-activated aminohexylderivative of sepharose $4 \mathrm{~B}$ as a new versatile immunoabsorbant. Immunochemistry. 12: 273-278.

39. Sjogren, H. O., I Hellstrom, S. C. Bansal, G. A. Warner, and K. E. Hellstrom. 1972. Elution of "blocking factors" from human tumors capable of abrogating tumor-cell destruction by specifically immune lymphocytes. Int. J. Cancer. 9: 274-283.

40. Izui, S., P. H. Lambert, N. Carpentier, and P. A. Miescher. 1976. The occurrence of antibodies against single-stranded DNA in the sera of patients with acute and chronic leukemia. Clin. Exp. Immunol. 24: 379-384.

41. Levine, G. B., P. E. Mills, and W. V. Epstein. 1967. Circulating IgG globulin anti-IgG globulin complex in a patient with carcinoma of the lung and severe neuromyopathy. J. Lab. Clin. Med. 69: 749-757.

42. Lewis, M. G., T. M. Phillips, K. B. Cook, and J. Blake. 1971. Possible explanation for loss of detectable antibody in patients with disseminated malignant melanoma. Nature (Lond.). 232: 52-53.

43. Hartmann, D., and M. G. Lewis. 1974. Presence and possible role of anti-IgG antibodies in human malignancy. Lancet. II: 1318-1320.

44. Klein, G., M. Steiner, F. Wiener, and E. Klein. 1974. Human leukemia-associated anti-nuclear reactivity. Proc. Natl. Acad. Sci. U. S. A. 71: 685-689.

45. Steiner, M., E. Klein, and G. Klein. 1975. Antinuclear reactivity of sera in patients with leukemia and other neoplastic diseases. Clin. Immunol. Immunopathol. 4: 374-381.

46. Russel, A. R., and J. H. Pope. 1976. Reactivity of antibody in acute myeloid leukaemia with proliferationassociated nuclear antigen(s). Clin. Exp. Immunol. 23: 83-90.

47. Day, N. K., J. B. Winfield, T. Gee, H. Teshima, and H. G. Kunkel. 1976. Evidence for immune complexes involving anti-lymphocyte antibodies associated with hypocomplementaemia in chronic lymphocytic leukemia (CLL). Clin. Exp. Immunol. 26: 189-195.

48. Hersh, E. M., J. P. Whitecar, K. B. McCredie, G. P. Bodey, and E. J. Freireich. 1971. Chemotherapy, immunocompetence, immunosuppression and prognosis in acute leukemia. N. Engl. J. Med. 285: 1211-1216.

49. Soothill, J. F., and M. W. Steward. 1971. The immuno- pathological significance of the heterogeneity of antibody affinity. Clin. Exp. Immunol. 9: 193-199.

50. MacLennan, I. C. M., D. G. L. Gale, and J. Wood. 1975. Resistance of certain leukaemic myeloblasts to immunological attack. Int. J. Cancer. 15: 995-999.

51. Bloch-Shtacher, N., K. Hirschhorn, and J. W. Uhr. 1968. The response of lymphocytes from non-immunized humans to antigen-antibody complexes. Clin. Exp. Immunol. 3: 889-899.

52. Harris, G. 1968. Further studies of antigen stimulation of deoxyribonucleic acid synthesis in rabbit spleen cell cultures. II. The effects of specific antibody. Immunology. 14: 415-423.

53. Moller, G. 1969. Induction of DNA synthesis in normal human lymphocyte cultures by antigen-antibody complexes. Clin. Exp. Immunol. 4: 65-82.

54. Oppenheim, J. J. 1972. Modulation of in vitro lymphocyte transformation by antibodies: enhancement by antigen-antibody complexes and inhibition by antibody excess. Cell. Immunol. 3: 341-360.

55. Nossal, G. J. V., and B. L. Pike. 1974. In Immunological Tolerance: Mechanisms and Potential Therapeutic Applications. D. A. Katz and B. Benacerraf, editors. Academic Press Inc., New York.

56. Gorczynski, R., S. Kontiainen, N. A. Mitchison, and R. E. Tigelaar. 1974. In Cellular Selection and Regulation in the Immune Response. G. M. Edelman, editor. Raven Press, N. Y.

57. Kontiainen, S., and N. A. Mitchison. 1975. Blocking antigen-antibody complexes on the T-lymphocyte surface identified with defined protein antigens. Immunology. 28: 523-542.

58. McKearn, T. J., F. P. Stuart, and F. W. Fitch. 1974. Antiidiotypic antibody in rat transplantation immunity. I. Production of anti-idiotypic antibody in animals repeatedly immunized with alloantigens. J. Immunol. 113: 1876-1882.

59. Nisonoff, A., and S. A. Bangasser. 1975. Immunological suppression of idiotypic specificities. Transplant. Rev. 27: $100-134$.

60. McKearn, T. J., Y. Hamada, F. P. Stuart, and F. W. Fitch. 1974. Anti-receptor antibody and resistance to graft-versus-host disease. Nature (Lond.). 251: 648-650.

61. McKearn, T. J. 1974. Anti-receptor antiserum causes specific inhibition of reactivity to rat histocompatibility antigens. Science (Wash. D. C.). 183: 94-96.

62. Binz, H., J. Lindenmann, and H. Wigzell. 1973. Inhibition of local graft-versus-host reaction by anti-alloantibodies. Nature (Lond.). 246: 146-148.

63. Workshop on prognostic factors in human acute leukemia. In Advances in the Biosciences. 1975. T. M. Fliedner and S. Perry, editors. Pergamon Press, New York. 